\title{
Some human actions in the destruction and construction of culture and nature - the Merafong region as a case study
}

\author{
ELIZE $S$ VAN EEDEN ${ }^{*}$
}

\begin{abstract}
For at least the past 180 years the Merafong Municipal region in the Gauteng Province of South Africa, (of which the Wonderfontein Catchment forms a part) has strongly relied on the primary sector for its economic existence and development. In the process some human actions, also related to serious water contamination/pollution, have resulted in phases of constructions ${ }^{1}$ as well as economic and health destructions. Differences over whose environment and whose nature it is spontaneously developed, with sometimes less friendly outcomes. The 'end result' up to 2006 is a complicated scenario experience, similar to that of many other regions or local areas, but also very unique and somewhat frightening. The long term focus of this article is to exchange knowledge $^{2}$ on the region with the objective to contribute towards creating a sustainable environment by ensuring closer co-operation between the various economic active cultures operating or functioning in the Merafong municipal region. In this article four aspects are covered.
\end{abstract}

Keywords: Merafong municipality, Wonderfontein, North-West Province, water-related health, water pollution, gold mining, sinkholes, uranium pollution.

\section{Introduction}

It probably can be said that the Wonderfontein Catchment in Merafong is one of the most well-documented, well-researched areas in South Africa.

* School of Basic Sciences, North-West University.

1 Construction in this article reflects the act of constructing, or manner in which something is constructed. See Collins English Dictionary, 1st Edition (Glasgow: Scotland, 2004), p. 364.

2 Transdisciplinary knowledge in this context implies scientific contact or exchange among disciplines to produce outcomes on issues beyond or above disciplines. Compare Grolier, The new book of knowledge dictionary, Vol. 1, A-7L, p. 683. 


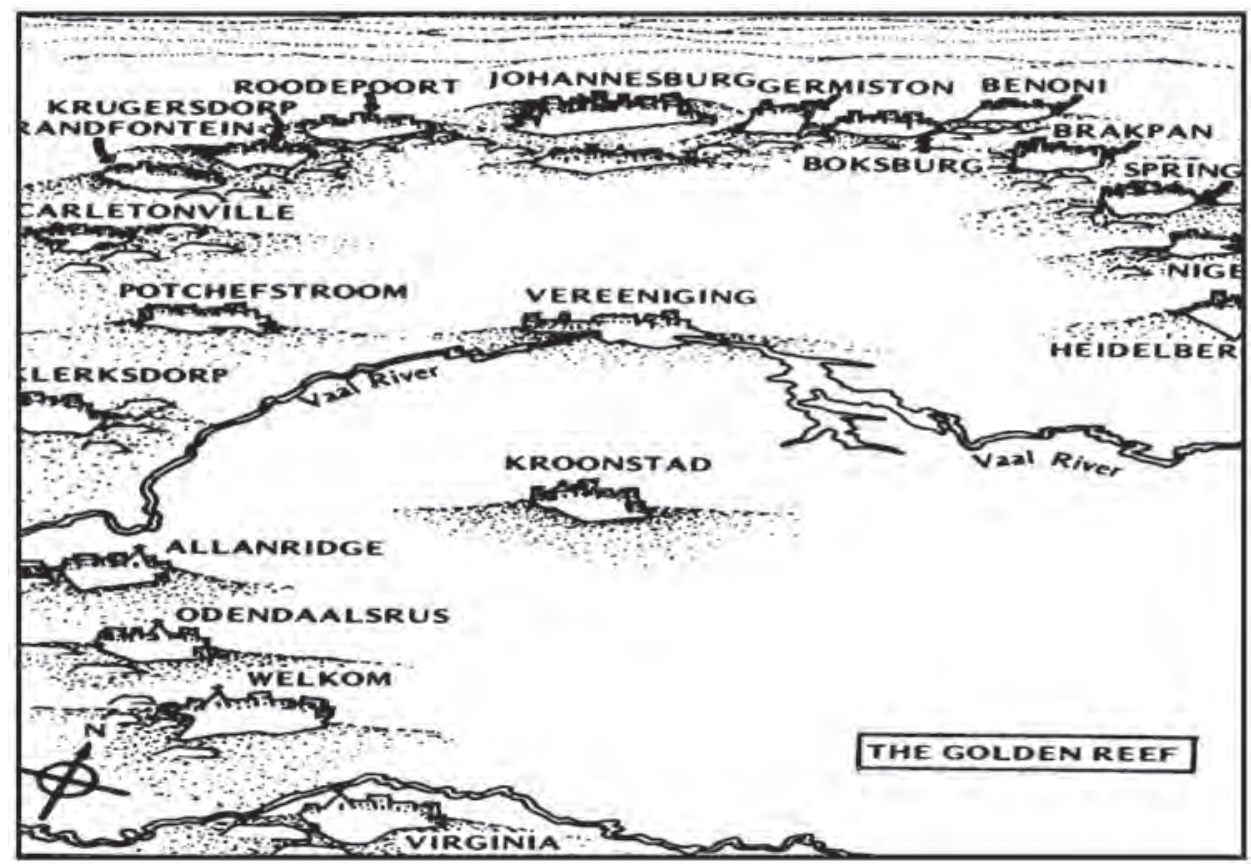

IIlustration 1: Geographical location of Merafong (Carletonville) in the West Wits Gold Line area

Especially as far as certain aspects of the environment is concerned. One of the major reasons for this is because of the rich gold bearing ores lying deep below the Dolomitic aquifers, discovered in the late 1800 s. These were protected until the cementation process - used from in 1934 in the area and which allowed mine shafts to penetrate through the water bearing geology - irrevocably changed the ecosystem.

The lure of vast tax profits moved government to permit the dewatering of four Dolomitic aquifers since the 1950's to exploit the gold and uranium ores. This by the eighties and currently appeared to have been a short-sighted undertaking.

The discussion that follows only sketches some of the developments to the present, but mainly highlight some human actions - related to serious water contamination or pollution - that apparently have resulted in phases of constructions ${ }^{3}$ as well as economic and health destructions.

3 Contstruction in this article reflects the act of constructing, or manner in which something is constructed. See Collins English Dictionary, 1st Edition (Glasgow: Scotland, 2004), p. 364. 


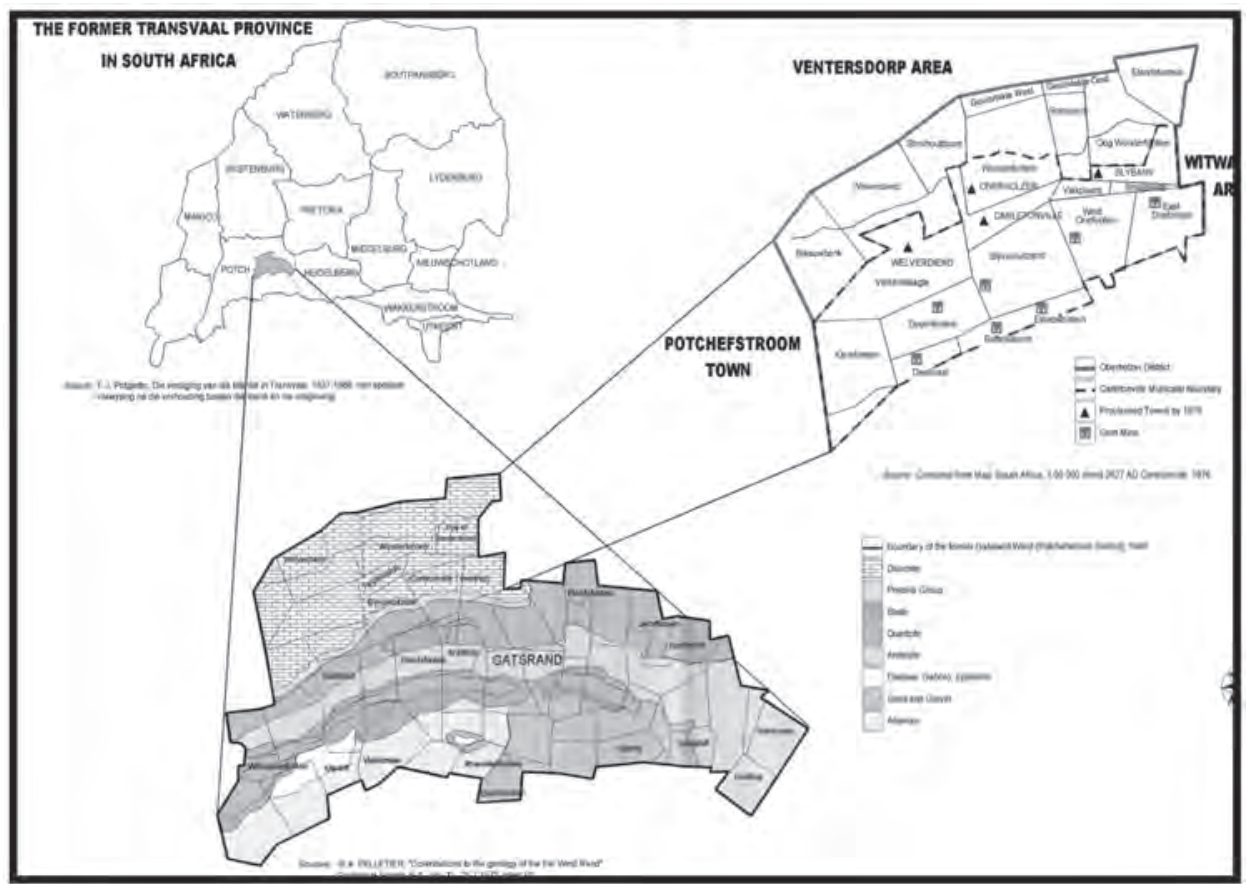

\section{Illustration 2: Historical and Geological features of the Wonderfontein Catchment}

\section{Nature and culture ${ }^{4}$ in Merafong - a short historical perspective}

Merafong as study area has been explored by many scientists from a variety of disciplines. Amongst others, thery have contemplated the topographical, geographical, geological and historical features before and after human interference have been recorded. These, however, will not be the key discussion for this article as indicated in the introduction. ${ }^{5}$ In essence the catchment of the Wonderfonteinspruit in the present-day Merafong municipal district (formerly Carletonville), also

4 Culture (from the Latin cultura stemming from colere, meaning 'to cultivate), generally refers to patterns of human activity and the symbolic structures that give such activity significance. Different definitions of 'culture' reflect different theoretical bases for understanding, or criteria for evaluating, human activity. In this discussion culture simply implies an appreciation and understanding of the customs and civilisation of groups of people in the community and the economic sector. Definition obtained from www.Wikipedia.org.za (8 Dec. 2006).

5 The features as referred to in the article has been covered in E.S. Van Eeden, A.B. de Villiers, A.H. Strydom, \& E.J. Stoch, 'Mines, people and sinkholes - an analysis of the Carletonville Municipal Area in South Africa as case study regarding politics of secrecy' Historia 47(1), May 2003; E.S. van Eeden, 'Nederlandse emigrante op Wonderfontein 1928-1969 - 'n suksesvolle mislukking onder die vaandel van stamverwantskaps- en ekonomiese motiewe', Historia, 46(1), May 2001. 
sources the Mooi River (that runs through Potchefstroom) east of the Boskop Dam. It is a dolomite area that formerly featured natural springs with unique fauna and flora.

This region, currently known as the Merafong Municipal region, ${ }^{6}$ existed long before recorded history. However, it was human actions and activities as a consequence of migration, environmental utilisation and exploitation since the $19^{\text {th }}$ century that eventually resulted in the civilised settlement of a variety of cultures over decades. ${ }^{7}$ In the process the environment was transformed to accommodate especially mining activities. From a 2006 perspective this exciting economic boost of the time turned out to be one of the most destructive economic choices of the $20^{\text {th }}$ century as far as the natural habitat and inhabitants (especially those relying on the farming potential of the area) are concerned.

Economic activity in the Merafong region is recorded since the $1850 \mathrm{~s} .^{8}$ The Digoya or Leghoya is regarded as one of the first tribes to have been in the area for some time. ${ }^{9}$ Furthermore Rasmussen's research brought him to an account that the Ndebele of Mzilikazi lived at the Vaal. ${ }^{10}$ W.C. Scully ${ }^{11}$ also reported some movement by Mzilikazi who had built his 'great place', Ezinyosini ('the place of the bees'), near the site of present Potchefstroom on the Mooi River, about fifty miles west of the Suikerbosrand. Though this prominent leader's stay in the Mooi River was short, traces of human destruction, as a result of war during the difaqane movement, were recorded by some European hunters and explorers in the interior. During ca. 1825-1878 it was the baKwena ba Molotšwane ${ }^{12}$ - who eventually settled at Thaba 'Nchu that were partly visible in the Gatsrand or 'Gatsrandberg'. ${ }^{13}$

6 Merafong was previously known as the Carletonville Municipal area since the 1960s and earlier (approx. 1840-1959) known as the Gatsrand area/Ward.

7 Compare E.S. van Eeden, 'Land tenure and reform in South Africa: Its history and the role of History with regard to land claims as officially proposed: a case study on the farm Deelkraal IQ 142, North West Province'. (Article presented for the SAHJ, 2006 to be peer reviewed).

8 E.S. van Eeden, 'Die geskiedenis van die Gatsrand vanaf die vestiging van die Trekkergemeenskap omstreeks 1839 tot die proklamering van Carletonville in 1948' (MA. PU vir CHO, 1988).

9 A. Anderson in J. Walton, J. Walton, Early Ghoya settlement in the Orange Free State, Memoir 2, 23, 26.

10 R. Kent Rasmussen, Migrant Kingdom: Mzilikazi's Ndebele in South Africa, 46-47.

11 R. Kent Rasmussen, Migrant Kingdom: Mzilikazi's Ndebele in South Africa, 48.

12 Davenport refers to one of the three subordinates of Moshweshwe as Moletsane among the Tlokwa. See T.R.H. Davenport, South Africa. A modern history, Fourth Edition, pp. 134-135. This group is a younger splintering of the older baKwena ba Molepole.

13 P.L. Breutz, Die stamme van die distrik Ventersdorp, 103-105; Dept. of Native Affairs, Anon., 'A short history of the Native Tribes in the Transvaal (1905)', 26. 
White settlers from the Cape Colony also migrated to the northwestern parts ${ }^{14}$ of the later Zuid-Afrikaansche Republiek. These parts ultimately became known as the Gatsrand Ward ${ }^{15}$ and were mainly utilised for farming purposes before the 1930s.

While a Dutch Settlement on the farm Wonderfontein in the late twenties further revived the local economic activities into much more than merely farming, active mining accelerated from $1934 .{ }^{16}$ The establishment of the first three gold mines, Blyvooruitzicht (1937), WestDriefontein (1945) and Doornfontein (1947), ${ }^{17}$ raised the expectations of entrepreneurs. Several towns were founded in the area. They were West Wits (1937), Oberholzer (1939), Bank (1940), Welverdiend (1942), Blybank (1947) and Carletonville (1948). ${ }^{18}$ Carletonville, which was proclaimed on 20 January 1948, was the sixth town to develop in the mining area in less than one decade. ${ }^{19}$ It was within this setting that the economic development of the Carletonville area (as part of the Oberholzer district) in the Far West Rand (nowadays the Merafong area as part of the Gauteng Province) took place. ${ }^{20}$

\section{Aspects of human involvement in the construction or destruction of culture and nature in Merafong since the start of gold mining activities}

In the past century mining in the West Rand, amongst others, are accused of serious water contamination or pollution. Their presence

14 P.J. van der Merwe, Die noordwaartse beweging van die boere voor die Groot Trek, 1770-1842 (Kaapstad: Burger Boekhandel, 1957), pp. 180, 205, 208, 282.

15 E.S. van Eeden, 'n Historiese perspektief op die herkoms van die naam Gatsrand', Nomina Africana, (1996).

16 E.S. van Eeden, 'Nederlandse emigrante op Wonderfontein 1928-1969 - 'n suksesvolle mislukking onder die vaandel van stamverwantskaps- en ekonomiese motiewe', Historia, 46(1), May 2001, pp. 54-91; R. Macnab, Gold their touchstone: Goldfields of South Africa, 1887-1987 - a centenary story, (Johannesburg: Johathan Ball, 1987), pp. 121.124.

17 R. Macnab, Gold their touchstone: Gold Fields of South Africa, 1887-1987, a centenary story (Johannesburg, 1987), pp. 64-161.

18 Unie van Suid-Afrika, Departement van Handel en Nywerheid, jaarverslag no. 3, Raad vir die Ontwikkeling van Natuurlike Hulpbronne, 1 Januarie-31 Desember 1950, Pretoria, 1950, pp. 34-35; jaarverslag no. 6, ... , 1 Januarie-31 Desember 1953, Pretoria, 1953, p. 19 and Carletonville Munisipaliteit, CM, Titelvoorwaardes, 1937-1960.

19 Interim Archive [IA], Carletonville Municipality [MCV], file 22/1(b)(2), Dorpe: memorandum i.v.m. die verskynsel van sinkgate en grondbeweging in dolomitiese gebiede en die uitwerking wat dit vir die toekomstige ontwikkeling van Carletonville inhou, 17.4.1976, p. 6.

20 E.S. van Eeden, 'So long gold mines - long live industries ? : a case study of Carletonville's battle for economic survival', (Paper presented at the Economic History Society Conference, 5-6 September 1996, University of the Witwatersrand, Johannesburg).

TD, 2(2), December 2006, pp. 409-430. 
and water related activities have apparently resulted in phases of constructions ${ }^{21}$ as well as economic and health destructions. ${ }^{22}$ Some of these are discussed:

\subsection{Construction}

Before gold mining became the primary economic activity in the Merafong region since the 1930s only a few trading stores did business in the area. By 1951 the number of businesses in the immediate surroundings of the gold mines had more than doubled. ${ }^{23}$

On 1 July 1959 the Local or West Wits Area Committee's dream was realised when Carletonville became an independent municipality. ${ }^{24}$ The newly demarcated area that extended from the towns Welverdiend towards Bank in the east and up to the Gatsrand Hills in the south also included the areas leased by the gold mines Doornfontein, Blyvooruitzicht and West-Driefontein, as well as the later East Driefontein, Elandsrand, Deelkraal and a part of the Western Deep Levels mining area. ${ }^{25}$

Merafong (Carletonville), as recorded in 1952, had already proclaimed three town extensions and one extension in the neighbouring town of Oberholzer. ${ }^{26}$ By 1995 the number of extensions had more than quadrupled. ${ }^{27}$ This high expansion rate, however, did not necessarily imply or guarantee a balanced economic sector. Mining activities became the dominant sector (also see diagram 1 for labour statistics) and also changed the face of an environment that has always been known for its natural springs and cave features.

21 Contstruction in this article reflects the act of constructing, or manner in which something is constructed. See Collins English Dictionary, 1st Edition (Glasgow: Scotland, 2004), p. 364.

22 E.S. van Eeden, 'Aspects of cultural life on the west rand, with specific focus on the effect of mining development on the cultural experience of the Carletonville community' (Reworked version of a paper presented at the South African Society for Cultural History, Transvaal Regional Branch, 7 March 1997, Public Library of Springs, Springs).

23 E.S. van Eeden, 'Ekonomiese ontwikkeling en die invloed daarvan op Carletonville, 1948-1988. 'n Historiese studie' (Ph.D. thesis, PU for CHE), p. 210 diagram.

24 Rand Daily Mail, 2.7.1959, p. 6. Also compare with the manuscript of W. Hagan-Watson, 'Down memory lane: Blyvoor's first 20 years', pp. 1-10.

25 Unie van Suid-Afrika, Die provinsie van Transvaal, Offisiële koerant, CLXIX, 24.6.1959, kolomme 11-14; and Carletonville (Municipality), Local Area Committee (LAC), Minutes: minute, 18.6.1959, pp. 6-7. [All these mines adopted new names for themselves after the beginning of the new political dispensation of 1994.]

26 Carletonville (Municipality) local Area Committee (LAC) file T6/13(2), Town and regional planning: West Wits Local Area Committee, Dec. 1952, p. 26.

27 Carletonville Herald, 6.11.1987; Urban Dynamics, Greater Carletonville/Fochville subregional structure plan, March 1995. 
Through all the years its economic links with Merafong were associated with a labour need in the various economic sectors of this region. Another black township, Wedela, has also developed since 1978 after the Elandsrand gold mine started its activities. ${ }^{28}$ In many ways these developments within the structures of the relatively young local municipality(ies) could be rated as economically and socio-culturally constructive because in the short term it produced prosperity to a steadily growing, culturally diverse, economically active population.

\section{DIAGRAM ONE}

EXTENT AND DISTRIBUTION OF FORMAL SECTOR EMPLOYMENT OPPORTUNITIES, 1995

\begin{tabular}{|l|l|l|}
\hline $\begin{array}{l}\text { MERAFONG } \\
\text { REGION }\end{array}$ & EMPLOYMENT & $\begin{array}{l}\text { \% OF REGIONAL } \\
\text { EMPLOYMENT } \\
\text { OPPORTUNITIES }\end{array}$ \\
\hline Khutsong & $*$ & 6.5 \\
Carletonville & 5712 & 0.2 \\
Wedela & $*$ & 89.8 \\
Mines & 155 & 2.0 \\
Rural & 78791 & 100.0 \\
TOTAL & 1761 & 87763 \\
\hline
\end{tabular}

No formal figures available

Another positive reflection of constructive development within the Merafong cultural setting was the prominent featuring of the local gold mines in the South African economy and the world market. ${ }^{29}$

28 Carletonville (Municipality), [LAC] Minutes: minute, Ondersoek ingevolge die Wet op Groepsgebiede 1950, Wesrand-Streek, 24.9.1957; 20.6.1957; 11.2.1958. Urban Dynamics, Greater Carletonville ..., 1995.

29 Carletonville (Municipality), [LAC] Minutes: minute, Ondersoek ingevolge die Wet op Groepsgebiede 1950, Wesrand-Streek, 24.9.1957; 20.6.1957; 11.2.1958. Carletonville (Municipality), CM, Council minutes; vergadering van die Bestuurskomitee, 9.1.1989; South African Institute of Race Relations, Race relations survey, 1988/89, p. 419. 
Not only did it secure millions for the State treasury, ${ }^{30}$ but it also revolutionised the local town infrastructure.

Gold mine companies also took it on them to supply not only funds, but also to make available expertise to assist in improving the local infrastructure. The building of supply roads, the provision of water and electricity as well as the development of school buildings, sporting grounds, cultural and recreation activities together with the financial and administrative liabilities that went along with it ${ }^{31} \mathrm{com}-$ menced virtually problem free.

The black township Wedela, situated between Elandsrand and Western Deep Levels gold-mines, for example, is a typical success story for which Anglo American was mainly responsible. ${ }^{32}$

In 1996 the formal population figure of the district was said to be $204000 .{ }^{33}$ This is an increase of approximately 30000 since $1991 .^{34}$ More than ever before the community structure changed into having a cosmopolitan character. For older inhabitants the presence of English-speaking whites as well as the variety and number of black ethnical groups, of whom some squatted due to a lack of houses, were necessary changes to which they had to adapt. ${ }^{35}$

As a consequence, the economic advantages and opportunities the exploration of gold created apparently outweighed any emotional distress suffered in response to change that may have occurred. ${ }^{36}$

By 1996 the $23.58 \%$ contribution of the Carletonville gold mining industry to the total gold production of South African mines undoubtedly had proved its strength. ${ }^{37}$ (See diagram 2 for the output of the gold mines).

30 E.S. van Eeden, Ekonomiese ontwikkeling ..., pp. 191-192; E.S. van Eeden, Carletonville ..., p. 237.

31 E.S. van Eeden, Ekonomiese ontwikkeling ..., chapter four.

32 E.S. van Eeden, Ekonomiese ontwikkeling ..., chapters two, four, five and seven.

33 Compare Republic of South Africa, Central Statistical Services, Population Census 1991, Report 03-01-02, Geoghraphical distribution of population; Carletonville Munisipaliteit, Urban Dynamics, Greater Carletonville ..., 1995.

34 Compare with Union of South Africa, Department of Commerce and Industries, Annual report no. 8, Council for the Development of Natural Resources, 1 January-1 December 1955, p. 9; PU vir CHO, Voortgesette streekopname van Beheerde gebied no. 2 ..., verslag no. 3, 1956/57, p. iii.

35 E.S. van Eeden, Ekonomiese ontwikkeling ..., compare with pp. 44 and chapter seven; CM, LAC, file N9/7/149 NAD, Komitee Wes Witwatersrand Naturellesake: vergadering Naturellesake Onderkomitee, 21.3.1958; file N79/10/149, West Wits Plaaslike Gebiedskomitee, huisvesting van Naturelle op privaateiendom, 1956.

36 Compare with E.S. van Eeden, Carletonville ..., pp. 172-173, 237.

37 See E.S. van Eeden, Carletonville ..., pp. 7-10. 


\section{DIAGRAM TWO}

CONTRIBUTION OF CARLETONVILLE'S GOLD MINES TO GOLD PRODUCTION IN SOUTH AFRICA BY JANUARY 1996 (in kg. fine gold)

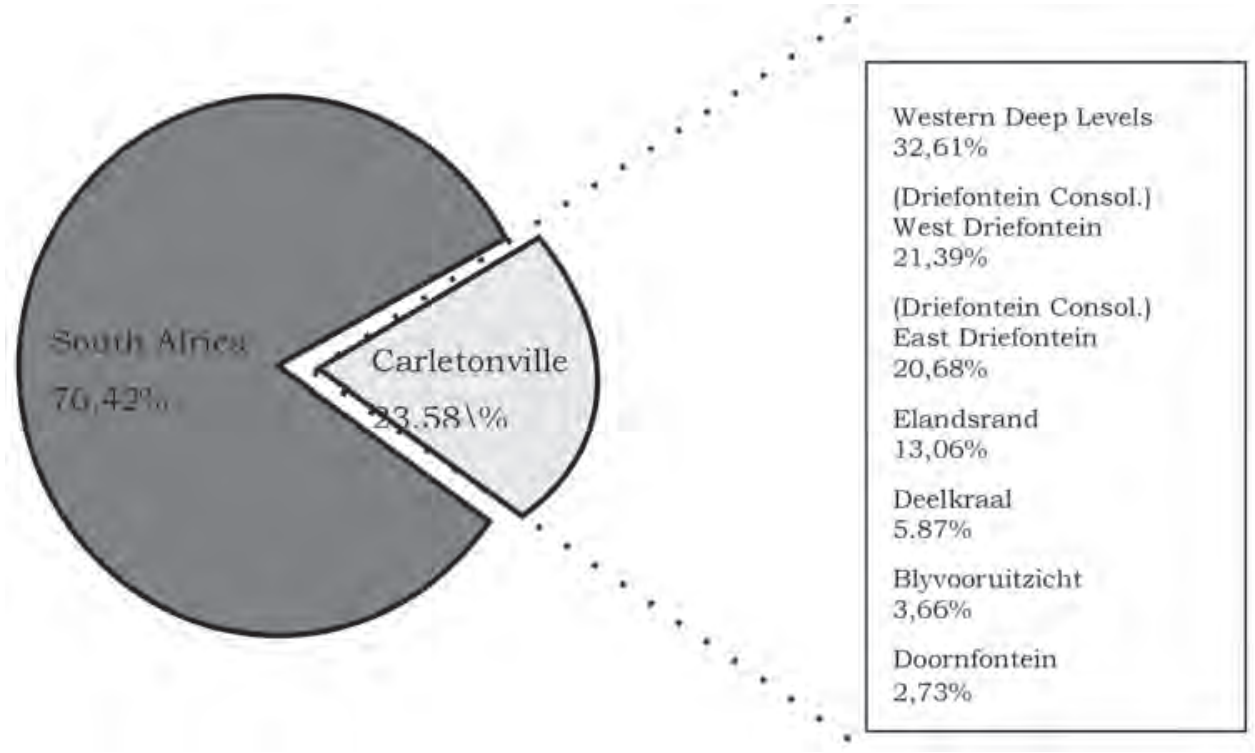

In looking thus at the infrastructure in general it appears as if the gold mining industry has done its part to ensure that the Carletonville area attracts investors and newcomers. An accusation might be that the industry mainly stimulated and initiated town development for their benefit and to meet their own needs. As far as a healthy framework for economic development was concerned it was left to local government to initiate. For years a partial absence of mutual co-operation and exchange of ideas between the local government of Carletonville and the local mining industry also contributed to the maintenance of the economic status quo. ${ }^{38}$ The de-proclamation of local territory brought an end to this silence in $1994 .{ }^{39}$

\subsection{Destruction}

It is unfortunate that the mines as the dominant constructive party in the Merafong area also are the dominant destructor.

38 Compare the attitude between council and the mines in E.S. van Eeden, Ekonomiese ontwikkeling $\ldots$, pp. 22-42 and chapter five.

39 Compare with interview, Mr D.O. Ndzeku/E.S. van Eeden, 20.8.1996; interview, Mr B. Strydom (chief town planner, Carletonville)/E.S. van Eeden, 16.8.1996. 


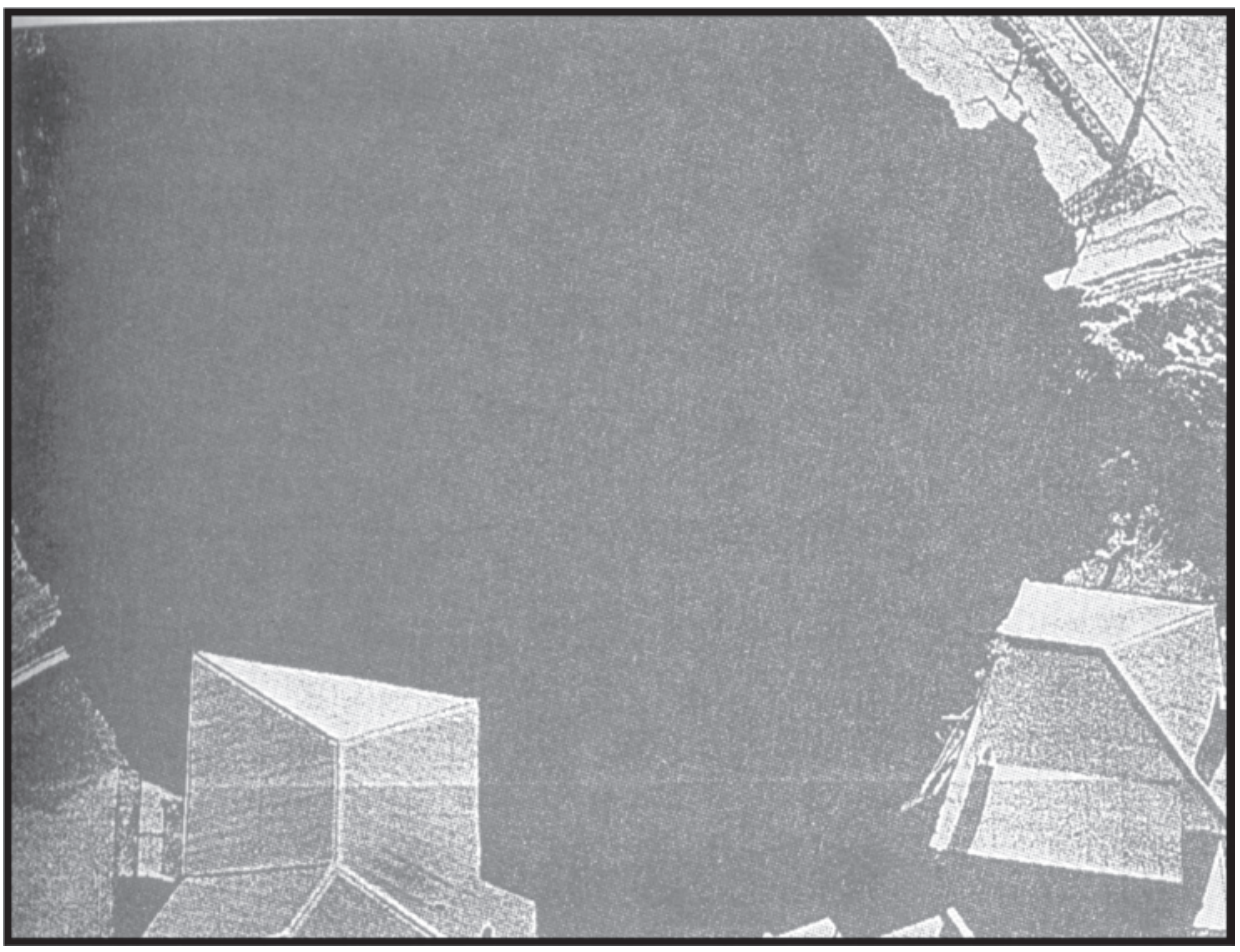

Illustration 3: The sinkhole on Blyvooruitzicht, August 1963.

\section{Dewatering and cementation}

For years the presence of underground water in the Wonderfontein catchment not only destructed gold mine development, but it also caused fear that water depositories might endanger the lives of mineworkers underground. The economically inspired decision to pump out the surplus water gradually, destroyed the local water resources. Sinkholes, related to dewatering, were manifested in the Venterspost area by 1940. In the 1950s the link between a drop in the water table in the Oberholzer Compartment also decreased the flow of the springs and triggered ground movement.

For decades this geological fact was denied by the affected members of the Mining Industry. The Venterspost Eye already stopped flowing during 1947. These events alarmed the members of the Oberholzer Irrigation Board. In 1948 they petitioned the then Secretary of Water Affairs with concerns in respect of the possible consequences of injecting cement to curtail the flow of water in the Dolomitic fissures and the resulting failure of the springs. As a defined 'public stream' (Water Act No. 54 of 1956), the full responsibility for water was placed under the Minister of Water Affairs, who appointed an Inter-Departmental Committee under the Chairmanship of the Secretary for 
Water Affairs to investigate the Dolomitic water problems.

In a confidential study in 1957 by the Council for Scientific and Industrial Research (CSIR), on behalf of New Consolidated Gold Fields Limited, the conclusion reached was that within a period of three months, about $30 \%$ of the water pumped into the sinkhole by Blyvooruitzicht returns to West Driefontein, about 35\% returns to Blyvooruitzicht, and only 15\% leaves the dyke system through the Oberholzer Eye.' So confidential was this report that it took considerable effort on the part of Dr G. J. Stander, the Director of the National Institute for Water Research, to obtain a copy which was only 'lent' to him and had to be returned. ${ }^{40}$

On 10 February 1964, Dr Stander submitted a Confidential response to the Final Report of the Inter-Departmental Committee in which he complimented the Committee for the detailed work done, but pointed out that his Institute was not consulted. In the view of Dr Stander the following aspects needed attention:

- the danger of pollution;

- the quality of the water that would reach the different communities;

- the protection of a National Asset (the Dolomitic compartments should not be used as dustbins); and

- a need for pollution-prevention planning.

The advice of Dr Stander appears to have been ignored by the State Co-ordinating Technical Committee and the subsequently established Far West Rand Dolomitic Water Association. ${ }^{41}$

The first Permit authorising the disposal of the surplus mine water outside the Dolomitic Compartment from which the water was drawn was issued in November 1964 whereas springs had already failed during 1947 and 1959, respectively. The flood event at West Driefontein $1968^{42}$ changed the situation dramatically.

The Bank Compartment which was considered to hold a volume of water too large to pump stopped flowing approximately four days after the rupture of the so-called Big Boy fault. This event triggered a spate of sinkholes in the Bank Compartment, which also dispelled any lingering doubts that there was a connection between the drop of the water table and accelerated ground movement. The dewatering of the Bank Compartment necessitated moving the water pumped by the Venterspost Mine across two dewatered Compartments to the

40 Manuscript, Memories, Dr E.J. Stoch, Jul. 2006; E.S. van Eeden, Ekonomiese ontwikkeling ..., chapters two \& four.

41 Manuscript, Memories, Dr E.J. Stoch, Jul. 2006.

42 E.S. van Eeden, Ekonomiese ontwikkeling ..., chapter four.

TD, 2(2), December 2006, pp. 409-430. 
Boskop or Turffontein Compartment. This was achieved by constructing a $610 \mathrm{~mm}$ aqueduct that debouched into the West Driefontein Canal at Bank. ${ }^{43}$

The consequences of dewatering, followed by sinkholes, were catastrophic. ${ }^{44}$ Not only was destruction experienced in every sphere of community life, but the impact on the environment was also felt because of the pumping of slimes into the sinkholes. ${ }^{45} \mathrm{As}$ far as the disastrous effect on environment is concerned, examples can be provided ad infinitum. For example, Minister Haak informed newspapers in 1966 that 1393039 tons of cement had already been pumped into boreholes alone. The cementation process continued to assure the survival of gold mines. This probably was millions and millions of tons. ${ }^{46}$

\section{Socio-economic destruction}

It is said that the media went overboard reporting on the rarity of sinkholes in the late sixties and seventies. In the process they disturbed the future of the general economy for a considerable time, especially after cracks and damages to buildings had been discovered and builders exposed subterranean caves during construction work. ${ }^{47}$ An article with the significant title Transvaal town becomes lopsided was published, which undoubtedly drew negative attention to the young mining town. ${ }^{48}$ However, no attempts by the Council to promote positive publicity ${ }^{49}$ prevented the so-called invisible giant from gnawing on the Carletonville area. ${ }^{50}$

As far as fatal incidences of sink-holes on mine property are concerned, several occurred after 1962 and in some cases caused a loss of lives, of which the grave death of the Oosthuizen family is probably the best known. Despite much criticism and a heavy financial burden as a result of this ecological disaster, mining authorities pulled it

43 Memories, Dr E.J. Stoch, Jul. 2006.

44 Compare with E.S. van Eeden, Ekonomiese ontwikkeling ..., all chapters.

45 Examples giving evidence of destruction are, amongst others, the so-called Green Belt in the urban area, the Bank Town and farming area and farming areas on WestDriefontein such as that of the Brink family. Compare with E.S. van Eeden, Ekonomiese ontwikkeling ..., all chapters and oral interview, Me. M. Liefferink, 21 Oct 2006.

46 See E.S. van Eeden, Ekonomiese Ontwikkeling ...

47 Union of South Africa, Department of Commerce and Industries, Annual report no. 12, Raad van die Ontwikkeling van natuurlike Hulpbronne, 1 Januarie 1959-1 Desember 1959, pp. 5; Unie van Suid-Afrika, Die provinsie van Transvaal, Offisiële koerant, CLXIX, 24.6.1959, kolomme 14-16.

48 Die Vaderland, 13.12.1962, p. 1; Dagbreek en Sondagnuus, 20.5.1962, p. 1; 16.12.1962, p. 2; The Star, 10.4.1963, p. 2; Die Transvaler, 11.4.1963, p. 1.

49 K. Steytler, 'Transvaalse dorp trek windskeef', Die Huisgenoot, 22.2.1963, pp. 8-13.

50 The Star, 23.1.1963, p. 1; 10.4.1963, p. 2. 
through and laid down a normalising pattern. As a result three of the gold mines mentioned earlier started with production, namely EastDriefontein (1968), Deelkraal (1974) and Elandsrand (1974). ${ }^{51}$

As far as town development is concerned, the picture appeared gloomier. The towns of Bank (after a drawback earlier in its history), ${ }^{52}$ Blybank and West-Wits were not as fortunate as Carletonville (to some extent) to survive this economic experiment. In January 1970, for example, occupants of Bank were advised to evacuate the town permanently because of the unstable surface caused by intense ground movement. ${ }^{53}$ In the years that followed extensive demolition of town dwellings in especially Carletonville Extensions 5 and 8 took place. ${ }^{54}$

By the 1980s the Bank area had not shared in the same process of recovery with Carletonville and Oberholzer. Some said that the gold which had 'attracted' these activities in the first place, was the cause of their 'exodus'. ${ }^{55}$

\section{Environmental destruction, water and farming}

Since the sixties most irrigation farmers in the Merafong area have been totally dependent on the water discharged by the mines for their livelihood. The first signs of crop failure were recorded during the 1964-1965 season in the irrigated wheat crop. By the next season a dramatic and widespread decrease in yields was only experienced on fields fed by the Lower Irrigation canal that relied on the surplus water discharged by the mines. The mysterious appearance of a white efflorescence was associated with the crop failures. ${ }^{56}$

51 E.S. van Eeden, Ekonomiese ontwikkeling ..., chapter four.

52 In 1958 the small Bank community was dissatisfied because Carletonville's development was favoured more by the gold mine authorities than that of Bank. One business person experienced the disapproval of a second town extension as follows: 'At one stroke of a pencil virtually the whole of our future developments, the proposed township, not to mention the substantial expense to which we have been put, is to be ruled out and nullified'. See Carletonville (Munisipaliteit), LAC, Lêer 61/1/239, Bank Extension no. Two; requests for foundation: letter, G. Fine and I.G. Slonimsky/Secretary Peri Urban areas Health Board, 15.11.1958.

53 Die Transvaler, 29.4.1970; Republic of South Africa, Debates by the House of Assembly, 24.5.1973, column 7633; Carletonville Herald, 30.1.1970.

54 Transvaal Archive, MCV, volume 43, file 70/2/1(1), Beplanning en ontwikkeling: vergadering, bestuurskomitee, 4.1.1966.

55 Carletonville Herald, 24.1.1969, p. 1; TBP, Argief van die Departement Bantoeadministrasie en -ontwikkeling (BAO), Band 3038, lêer C39/28/1108, Arbeidsburo Carletonville: brief, Vener, Mosdell, Suttners Stores, Spilkins Outfitters/Dept. Bantu Administration and Development, 24.4.1970; Carletonville (PU vir CHO), Verw. 3: onderhoud, E. Twaits (ex-businessman of the towns of Bank and Carletonville), 20.4.1989.

56 Manuscript, Dr Les Stoch, Jul. 2006; E.S. van Eeden, Economic development ..., chapter three. 
Some farmers who had not been as drastically affected by the water contamination as those in the Bank area experienced scattered incidents of subsurface hydro extraction on their farms. The water that was pumped out by the West Driefontein Mine was then channelled to the local Irrigation Board to relieve the farmers' shortage of water due to hydro extraction at two points. The fact that farmers were dependent on the goodwill of the mining sector had further weakened the economic position of farmers by 1966 . Mines in the region were already supplying water to more than 30 farmers whose bore-holes had dried up. After the sixties nothing remained visible of the once wellwatered Wonderfontein and the Eye of Wonderfontein, once a spot of scenic beauty. A network of irrigation canals was laid on by the mines to provide for the water needs of the farmers. ${ }^{57}$

Complaints from farmers that the West Driefontein mine had dumped polluted water with harmful mineral elements like boron and aluminium into the irrigation canals evoked widespread reaction. Some claimed that this affected the vegetation and animal life of the area. Examples of abnormal absence of seed during the harvest of buckwheat, maize and corn, the serious pigmentation of grass and clover planted for feeding purposes and the abnormal number of deaths, miscarriages and deformities that occurred in fish, goats and pigs were mentioned. ${ }^{58}$

Despite the diversity of soil types, planted crops and management systems the common factor was a disturbance of the calcium metabolism of the plants. The calcium depletion in the irrigated area was unexpected given the components in dolomitic water. The pathology in animals was found in sheep, goats, cattle and swine. The possible influence of contagious abortion and fibrosis had to be eliminated before a link between the symptoms and water quality could be suggested. The symptoms were joint problems in adult animals, abortions and deformities at rates previously not encountered in the area. Joints were more affected than the rest of the body which manifested as a stiffness of gait. Scour in a variety of animals was commonplace and massive internal bleeding in pigs occurred occasionally. Blood did not coagulate, while milk curdled. Both these events are related to calcium metabolism. Given the knowledge that both the Blyvooruitzicht and Driefontein Mines had active Uranium Extraction Plants, it was no great stretch of the imagination to link water quality to the problem as a generalisation and to suspect the presence of radio-isotopes

57 Compare E.S. van Eeden, Ekonomiese ontwikkeling ..., chapter three.

58 E.S. van Eeden, The impact of economic logic on the environment: a case study on the effect of subsidences, hydro extraction and hydro pollution on the agricultural industry of the Oberholzer district (Carletonville area), 1959-1972, Electronic Journal Monitors, H-Africa network, 1996. 
in the water'. Based on scientific research it was known that

Lead, Zinc, Strontium, Barium, Boron and a variety of radio-active isotopes could have an effect on the metabolism and that high doses of calcium alleviated some of the symptoms. ${ }^{59}$

Continuous allegations between a dissatisfied farming community and the mines probably led to the Deputy Minister's announcement in November 1967 that the concerns raised by the farmers would be investigated. Dr Nico Stutterheim of the CSIR chaired this process. During the same time the Farmers Union (FU) compiled a memorandum on the impact on animals and crops that was presented to the then Deputy Minister of Water Affairs, Mr Herman Martins. ${ }^{60}$ In this memorandum the presentation of 'an X-ray of a pig's hipbone was recorded: the osseous tissue had been eroded by astrochemical sarcoma, a type of cancer.' Dr Jerry Retief, a veterinarian who assisted in the compilation of the memorandum, made it clear that while 'the element responsible for the ... phenomena had not yet been traced' there was 'some or other element present that excreted the calcium from the osseous tissue' and that there was 'a possibility that radioactive isotopes could be responsible' but that 'this had not been proved'. In this memorandum Retief also amplified the following phenomena:

- Massive internal bleeding in pigs.

- Birth deformities, at least 50\% higher than before 1966.

- Radioactive isotopes such as SR and U that have a severe impact on the body. It was said that the body has an affinity for these isotopes. Radioactive isotopes replace calcium in the body and calcium in the milk gets eliminated rapidly.

- One or more elements are present which replace calcium in the bone tissue.

- It is possible that a radioactive isotope could be responsible, but that this has not yet been proved.

- The above phenomena are all factors that can point to radioactive isotope contamination from the uranium ores of the Witwatersrand ... ${ }^{61}$

By the eighties the mines had become the prime 'manager' of the agricultural areas in the Oberholzer district. ${ }^{62}$ Insufficient remuneration (if at all) to those individuals, farmers and local business men who experienced losses as a result of water (causing sinkholes or being

59 Memories Dr E.J. Stoch based on his own compilation of sources, Jul. 2006.

60 Compare Retief and Stoch, 1967 as in Circular No. 28/67, Letter, Chairman of the Far West Rand Dolomitic Water Association, 1967.

61 Obtained from E.J. Stoch, Memorandum, Krugersdorp Game Reserve: Animal mortality. V2, 13 May 2005, p. 4.

62 Compare e.g. the figures as presented by Urban Dynamics in 1995, p. 8.

TD, 2(2), December 2006, pp. 409-430. 
polluted) became another point of the complicated debate. Despite many efforts by several concerned environmental experts and human activists to address these accusations, they, are still falling on ignorant or clever, strategic mining management ears now in 2006. ${ }^{63}$ The debate about water pollution by the mines, and the effects on the farming community as well as the local community in general (especially in informal settlement areas and further west to Potchefstroom) is also continuing.

\section{Water-related health issues after 1990}

In this section a number of issues related to water pollution will be referred to as examples of why ordinary people wanted to have proper answers from mining authorities and water expertise on the mining payroll. Some of these are scientifically tested, others are based on speculation because of difficulties to prove scientific results on the spot or date that an event occurred, or even a long-term destruction that is not easily traceable. They are:

- Possible radiogenic impact. This can range from impaired mental capacity, through somatic changes, to genetic defects. This makes a direct linkage between cause and effect, tenuous in the extreme. Thus, if the potential source of future ills is hidden in the mist of time, those responsible for finding effective treatments will be searching in the dark for the causal agent(s) (thus Dr Stoch, 2006). In the early seventies the Committee regarding the Quality of Water in the Far West Rand issued a Final Report under the chairmanship of Dr Van der Merwe Brink of the CSIR. By 2006 this still was embargoed as confidential. As member of this Committee Dr E.J. Stoch did not approve of the Final Draft and prepared a minority report which Brink did not accept. Dr Stoch eventually agreed to sign a specific part, but on condition that the part he did not agree with will appear after his signature. His regards the outcome of this request as follows:

\footnotetext{
A final document was re-arranged over coffee and petit fours and was not signed by me. It was only recently that I managed to obtain a copy of the document and was rather dismayed at the content. Although it is stated in the Final Report that the Radium values were at the limit of the maximum allowable level, new light had been shed on the matter in terms of maximum concentration of radium in water ... ${ }^{64}$
}

63 Compare efforts from the Agricultural unions in the area since the sixties, the efforts by business expert J. van Rooyen and Me. M. Liefferink since the nineties. See previous sources as indicated as well as J. van Rooyen, Claim for damages, as a result of dewatering of the Oberholzer Water Compartment during the period 1957 to 1964 against The Far West Rand Dolomitic Water Association, West Driefontein Gold Mining Company Limited, and the State, Claim 11 November 1997.

64 Dr. E.J. Stoch, Memorandum, Krugersdorp Game Reserve: Animal mortality. V2, 13 May 2005, pp. 5-6. 
Much later, in Circular No. 26/95, the Chamber of Mines refers to the Report on Radioactivity in water sources of the Department of Water Affairs, a Phase 1 Report produced in 1995. Wymer (1995) advised the affected members 'that we have little choice but to accept that some of the radioactivity levels measured may indeed be cause for some concern. It (was) recommended that the mining industry should establish a proactive and open strategy for addressing the issue. It is only a matter of time before these results become public knowledge'.

Mr Henk Coetzee of the Council for Geoscience investigated the relative radio-isotope composition of the sediment as well as the inflorescence around the Turffontein Eye in about 1996 and concluded that there was an elevated level of radioactivity and that the source was most likely the mines (Coetzee, personal communication Dr Les Stoch). ${ }^{65}$

- Possible Uranium impact. Back in time, in 1965, the Chamber of Mines instituted a study on the 'In situ leaching of uranium from slimes dams and dumps'. ${ }^{66}$ Also based on the findings of Matic and Mrost (1964) it was concluded that 'pyrite-bearing slime is amenable to bacterially-assisted oxidation resulting in the production of ferric sulphate which is a lixivium for uranium'. Between $70 \%-$ $80 \%$ uranium was recovered in laboratory tests. D. van As, the Head of the Sub-division: Radioactivity of the Atomic Energy Board, also reported to the department of Mines that in comparison with the water from the Crocodile River, with the exception of the Bank Eye water, all the water from the Oberholzer area showed levels of Alpha- and Beta- activity that were much higher. The one sample had a $\mathrm{Ra}^{226}$ activity content of 27 pCit that exceeded the recommended permissible limit.

The mining authorities, though sufficiently equipped with the necessary expertise and technology, were somehow seldom able to come up with clear results from their investigation into the quality of water in the process of distribution over a distance of 60 to 80 kilometres. However, they were always quick to reject assumptions, even those based on scientific research. ${ }^{67}$

- Possible sediment impact. On 28 September 1992 at a meeting of irrigators to discuss their problems representatives of Gold Fields denied that the sediment came from the mines. According to their

65 Coetzee was also part of the controversial 2006 WRC report 1214/0/06.

66 (NBRI Project 5033/95026), as previously been reported on by Matic and Mrost (1964).

67 Compare WRC, H. Coetzee, F. Winde \& P.W. Wade, 'An assessment of sources, pathways, mechanisms and risks of current and potential future pollution of water and sediments in gold-mining areas of the Wonderfontein Catchment', WRC, Report no. 1214/1/06.

TD, 2(2), December 2006, pp. 409-430. 
delegate, the source of the problem was the dust from Bekkersdal informal settlement. A meeting with the then Manager of the West Driefontein Mine, Mr Syd Caddy followed and the denial was repeated. The farmers were even warned that the Mine had 'deep pockets' and would keep them in Court for ' 60 years'. ${ }^{68}$

A problem experienced was that the discharge of the mine was not being passed through any settling ponds, with the result that the silt settled in the canals and had to be removed on a regular basis. When the farmers had convinced the Minister of Water Affairs that they were entitled to better quality water, a member of DWAF indicated that he would oppose any change in the status quo as, according to him, the water was of a suitable quality. In order to alleviate the problem, the Oberholzer Irrigation Board was obliged to construct a number of scour sluices in the canal which were used to divert the sediment into the Wonderfonteinspruit. ${ }^{69}$

- The possible overdose of a large sulphate content. Dairy farmers in the Oberholzer area were the first to notice problems with the fertility of their animals, sometimes associated with birth defects that could not be linked to specific infections. Amongst others, problems were evident in the Sanrus Dairy Herd and the Rooipoort Herd of Mr Nortje. A diagnosis of blood samples indicated a deficiency of selenium. Eventually the conclusion was reached that a large sulphate content in water could induce a selenium deficiency. From a veterinarian examination of cows it was also orally exchanged that most of the cows of Mr Hennie Viljoen had enlarged livers. The same scenario played off regarding the chickens on the farm of $\mathrm{Mr}$ Jan Nel and the occurrence of an extensive infertility rate of Koi fish on the farm of a Mr Wiid close to the Turffontein spring (just outside Merafong's eastern border). ${ }^{70}$

- The possible impact of contaminated water on humans in the Wonderfontein mining area. Though the majority of inhabitants of Merafong receive water from the Rand Water Board for their daily consumption, people from informal settlements and some farming communities don't. They mostly rely on the water distributed by the mines into several dams. As far as the impact on humans was concerned, discussion with a number of medical specialists gave rise to concern that, in time, humans could be affected in the same way as the animals and that the matter deserved attention. By 2006 this matter had neither been addressed on a macro scale, nor on a micro scale. Assumptions and observations still prevailed with no

68 A comment made by Dr E.J. Stoch, 2006.

69 Minutes, Oberholzer Irrigation Board, ca 1992.

70 Dr. E.J. Stoch, Memorandum, Krugersdorp Game Reserve: Animal mortality. V2, 13 May 2005, pp. 8-10. 
funds and insufficient expertise available to scientifically follow up these accusations before the mines decided to purchase the properties. Amongst others, the following observations - with water pollution as a key detriment - were made over decades:

In the Blyvooruitzicht mining area, for example, the community were dependent on ground water for their daily needs. A teacher from the former Goudwes School in Carletonville that caters for academic under-achievers, noticed that a disproportionate number of children at the School lived at Blyvooruitzicht. ${ }^{71}$ Scientific references point to the fact that radioactivity in drinking water could lead to impaired intelligence in children and other haematological abnormalities. ${ }^{72}$ Bain and co-authors refer to the vulnerability of communities exposed to radioactivity in mine discharge, and the relatively high cost of analyses. Radioactivity is not solely linked to water, but can also enter the human body through digestion or inhalation..$^{73}$

Bain and authors were not the first to link communities to radioactivity in the surrounding areas of mines. In 1990 already Funke, in another WRC report, said the extent of the exposure of miners to radioactive materials in gold and uranium mines should be measured and countermeasures taken, if necessary. The extent of the exposure to the effects of radon gas ands its radioactive daughter products of the public living near tailings dumps also warrants investigation. ${ }^{74}$

Findings by the Kempster Committee to investigate the background of radioactivity in South African water were never shared with the general public:

- The daughter of a farmer, Mr Hennie Viljoen, suffered from severe stomach cramps when she ate beetroot salad made from beets grown in their own garden.

- South of the Gatsrand (close to the Kloof mine) the Berry family experienced severe medical problems.

71 Dr. E.J. Stoch, Memorandum, Krugersdorp Game Reserve: Animal mortality. V2, 13 May 2005, p. 4.

72 Compare WRC, C.A.R. Bain, H.J. Schoonbee, L.P.D. de Wet, \& J.J. Hancke, 'Investigations into the concentration ratios of selected radionuclides in aquatic ecosystems affected by mine drainage effluents with reference to the study of potential pathways to man' WRC Report No 313/1/94. Also compare the report by Herman Martins in 1967 which to a large extent focused on radioactivity. See Memorandum, Krugersdorp Game Reserve: Animal mortality. V2, 13 May 2005, p. 11, obtained from E.J. Stoch.

73 WRC, Report no. 313/94, Bain et al.

74 WRC, KV9/90, Pretoria, J.W. Funke, 'The water requirements and pollution potential of South African gold and uranium mines', p. 153.

TD, 2(2), December 2006, pp. 409-430. 
- In the late nineties Dr Veldsman of Potchefstroom expressed his concern about the incidence of pancreatic cancer in his patients, as five of the six cases came from the Carletonville-Fochville area (the latter a town a few kilometres south-west of Carletonville). Pancreatic cancer and radioactivity was positively linked by a medical specialist in Nashville, Tennessee - Professor Martin Sandler. ${ }^{75}$

Because of so many historical silences (a lack of reliable and substantial documents as well as solid evidence) on especially the part of Government and the Gold mining sector on water issues in the Merafong area it remains difficult - from a perspective formulated in 2006 - to gain a balanced perspective of the past. Community members felt that government and mining authorities had, in fact, made decisions that gave an impression that they regarded themselves as being above the law.

The economic advantages of exploring for gold in a very vulnerable geological environment far outweighed the well-being of the local people, many of whom had settled in the area because of possibilities offered by the gold mining activities. No ethical code was followed before and during the process of dewatering. The only tenet that was strictly observed was that of secrecy.

\section{Conclusion}

Of particular interest in this discussion on Merafong were the possible construction and destruction by the mines regarding the Wonderfontein environment, its water status and how it possibly affected its inhabitants and environment. Though the position of the state and the mining houses with regard to this construction and destruction of the Merafong area since 1935 were not explicitly debated in length, accusations are well-recorded. Some refer to the role of the mines and government as a 'from need to greed' process. Others feel that the public were bluntly mislead about the nature of the environmental and other pollution to which they were and still are victims. This secrecy is most probably financially related, and possible elements of corruption can certainly not be excluded.

Short-term economic gain has often left the general public badly off. Merafong's history mainly pointed out the mobilisation of the farming community against the mines and the national government. However, insufficient funds and limited acceptable opportunities to proof their

75 Obtained from E.J. Stoch, Memorandum, Krugersdorp Game Reserve: Animal mortality. V2, 13 May 2005, pp. 12-13. Also compare, WRC, Report no. 313/94, Bain et al ... 
experience of water contamination have resulted a mode of regarding their speculations as relative and scientifically dissatisfactory. It was only recently that individuals as caretakers of justice, and members of the academic community, queried the status quo in some research findings of the area. ${ }^{76}$

The powerless-like attitude of the local authority and the general public (the business community included) all mainly relates to financial reasons. On the one hand the will and need to survive as local government on behalf of several towns in the area, and on the other hand the undisputable need to have job security. Those individuals who have tried to declare a dispute in the long term were not effective in their efforts. ${ }^{77}$

Rumours about polluted water in 2006 were a still ongoing debate, and should not be ignored. Occasional complaints about the effect of water on man and especially animals and the environment still continued. ${ }^{78}$ In the past some members of the community who were dissatisfied did not see any other choice but to pack up and explore other options to recover financially or overcome the trauma. In 2000 water was still pumped from the dewatered compartments of e.g. Bank and Oberholzer, and by then it was estimated to consist of the natural groundwater recharge and water imported from Rand Water. With the exception of minor quantities, the mine reused the water and also supplied certain irrigation boards and individuals on a contractual basis. $^{79}$

From a national point of view the question of ethics and the human rights of those affected became insignificant issues. It appears that the State elected not to be accountable for the serious psychological and economic setbacks suffered by inhabitants of the area. The

76 Compare WRC, H. Coetzee, F. Winde $\&$ P.W. Wade, 'An assessment of sources, pathways, mechanisms and risks of current and potential future pollution of water and sediments in gold-mining areas of the Wonderfontein Catchment', WRC, Report no. 1214/1/06; oral interview, Me. M. Liefferink (Social justice activist), 21 Oct. 2006.

77 Compare J. van Rooyen, Claim for damages, as a result of dewatering of the Oberholzer Water Compartment during the period 1957 to 1964 against The Far West Rand Dolomitic Water Association, West Driefontein Gold Mining Company Limited, and the State, Claim 11 November 1997; Oral interview, Me. M. Liefferink, 21 Oct. 2006.

78 Compare J.C. Mc Millen, 'Better for it: how people benefit from adversity, 'Social Work, 44(5), September 1999, pp. 455-468; S. Brander, 'Practice issues: understanding aged holocaust survivors', Families in Society, 81(1), January-February 2000, pp. 66-75.

79 Difficulty in ensuring that farmers in the area benefited from the eye to water their crops in the late 1890's are known. Compare J. Shorten, Die verhaal van Johannesburg, (Voortrekkerpers; Johannesburg), pp. 53; 167-168; Also see the Rand Water Board's first minute book in 1903 covering the Wonderfontein water issue; E.S. Van Eeden, 'So long gold mines - long live industries. Carletonville's battle for economic survival,' South African Economic History Journal, November 1997.

TD, 2(2), December 2006, pp. 409-430. 
substantial cost that resulted from the exercise required to reverse the damage runs into millions of Rand. With regard to these events the financial drawbacks suffered by gold mines, specifically as a result of damage caused to the mining infrastructure and property as well as loss of lives of employees and their families, aroused concern. Farmers and some businessmen from time to time raised serious objections to the dewatering of compartments, and to the consequences of polluted water due to mining activity.

According to Frank Winde no investigation aimed at establishing possible health implications in affected communities has been conducted in the Wonderfonteinspruit area. An effort to assess associated health risks is further complicated by a number of facts including the lack of reliable data on effects of long-term low-dose exposure of humans to uranium in drinking water and limited understanding of the complex mechanisms and dynamics of uranium pollution and uranium transport in the aquatic environment. Uranium pollution, it is said, is not exclusively caused by historical mining activities but also by current operations. ${ }^{80}$

With the mines as the dominant economic sector in a process of moving out, the Wonderfontein catchment may be irreversibly destroyed if there is no constructive plan to properly manage the development of the area regarding concerns raised: this concerns a question mark regarding the future of people, the possibilities for farming, as well as for cultural and environmental sustainability (though some concerns may be bound to speculation). The role capitalism, racism and nationalism have played in this process then can be debated but this will never bring back what once was. Constructive global discussions on many similar examples worldwide should be explored and possible long term solutions posed by all stakeholders to apply to this unique micro community scenario of Merafong.

80 Compare F. Winde, Interactions between groundwater and surface water in dolomitic areas affected by Deep-level gold mining - examples from the Far West Rand goldfield (South Africa), CSIR, 'Abstracts of the Biennial Ground Water Conference 2005, 7-9 March, 2005, pp. 1-2; F. Winde, 'Challenges for sustainable water use in dolomitic mining regions of South Africa - a case study of Uranium pollution. Part 1: Sources and Pathways [ca. 2006. Source personally supplied by the author F. Winde to E.S. van Eeden]; Dept. of Water Affairs and Forestry, The determination and management of interaction between the surface and groundwater Resources in the Far West Rand Area, Phase 1: Situation Assessment, Vol. 1: Text, Feb. 2006. The quality of this document is seriously questioned by Dr. E.J. Stoch, especially the topographic part (Interview

Dr E.J. Stoch, 3 Nov. 2006). 